\title{
PENGARUH MODEL PEMBELAJARAN CTL BERORIENTASI TRI KAYA PARISUDHA TERHADAP HASIL BELAJAR MATEMATIKA SISWA KELAS III
}

\author{
Ni Luh Ayu Sariani \\ Universitas Pendidikan Ganesha \\ Email: yusariani25@gmail.com \\ I Made Suarjana \\ Universitas Pendidikan Ganesha \\ Email: suarjana_undiksha@yahoo.co.id \\ I Ketut Dibia \\ Universitas Pendidikan Ganesha \\ dibiaketut@yahoo.com
}

\begin{abstract}
Abstrak
Penelitian ini bertujuan untuk mengetahui perbedaan hasil belajar matematika antara siswa yang dibelajarkan menggunakan model pembelajaran CTL berorientasi Tri Kaya Parisudha,dengan siswa yang tidak dibelajarkan menggunakan model pembelajaran CTL berorientasi Tri Kaya Parisudha,terhadap mata pelajaran Matematikasiswa kelas III SD di Gugus III Semester II Kecamatan Banjar Kabupaten Buleleng tahun pelajaran 2017/2018. Populasi penelitian ini adalah kelas III SD di Gugus III semester II Kecamatan Banjar Kabupaten Buleleng yang berjumlah 130 orang. Sampel penelitian ini adalahsiswa kelas III SD Negeri 3 Dencarik berjumlah 20 orang sebagai kelompok eksperimen dan siswa kelas III SD Negeri 2 Dencarik berjumlah 25 orang sebagai kelompok kontrol. Metode pengumpulan data menggunakan metode tes yang berbentuk pilihan ganda dengan jumlah soal sebanyak 25 soal. Data dianalisis menggunakan analisis statistik deskriptif dan (uji-t). Berdasarkan hasil analisis, diperoleh $t_{\text {hit }}=3,22>t_{\text {tab }}$ $=1,68$. Hasil penelitian menunjukkan bahwa terdapat perbedaan yang signifikan hasil belajar matematika antara kelompok siswa yang dibelajarkanmenggunakan model pembelajaran CTL berorientasi Tri kaya Parisudhadan kelompok siswa yang tidak dibelajarkanmenggunakan model pembelajaran CTL berorientasi Tri kaya Parisudha pada siswa kelas III SD di Gugus III semester II Kecamatan Banjar Kabupaten Buleleng tahun pelajaran 2017/2018. Saran dari penelitian ini adalah agar dapat digunakan sebagai pedoman dalam penelitian lebih lanjut tentang model pembelajaran CTL berorientasi Tri Kaya Parisudha, dalam bidang matematika maupun bidang ilmu lainnya yang sesuai, serta peneliti juga diharapkan memperhatikan kendala-kendala yang di alami dalam penelitian ini sebagai bahan pertimbangan untuk perbaikan dan penyempurnaan penelitian yang akan dilaksanakan.
\end{abstract}

Kata-kata kunci: CTL, tri kaya parisudha, hasil belajar matematika

\begin{abstract}
This study aims to determine the results of learning mathematics between students who were taught using CTL learning model oriented Tri Kaya Parisudha, with students who are not in learning using CTL learning model oriented Tri Kaya Parisudha, to the subjects of Mathematics class III elementary school in Gugus III Semester II District Banjar Buleleng Regency Lesson year 2017/2018.The population of this research is class III elementary school in Gugus III semester II Banjar Subdistrict Buleleng District, amounting to 130 people. The sample of this research is third grade students of SD Negeri 3 Dencarik amounted to 20 people as experimental group and third grade students of SD Negeri 2 Dencarik numbered 25 people as control group.Methods of data collection using the test method in the form of multiple choice with the number of questions as many as 25 questions. Data were analyzed using descriptive statistical analysis and ( $\mathrm{t}-$ test). Based on the results of analysis, obtained thit $=3.22>\mathrm{ttab}=1.68$. The results showed that there was a significant difference of mathematics learning outcomes between groups of students who were taught using CTL model oriented Tri Kaya Parisudha and group of students who did not learn using CTL model oriented Tri Kaya Parisudha in third grade students of SD in Gugus III semester II of Banjar Regency of Buleleng year lesson 2017/2018. Suggestion of this research is to be used as guidance in further research about CTL model oriented Tri Kaya Parisudha, in the field of mathematics and other appropriate science field, also researcher also expected to pay attention to obstacles that experienced in this research as consideration for the improvement and refinement of the research to be carried out.
\end{abstract}

Keywords: CTL, tri kaya parisudha, mathematicslearning outcomes 


\section{Pendahuluan}

Menurut UU No 20 tahun 2003 pasal 1 ayat 1 tentang sistem pendidikan Nasional (2003) pendidikan adalah usaha sadar, dan terencana untuk mewujudkan suasana belajar, dan proses pembelajaran agar peserta didik secara aktif mengembangkan potensi dirinya untuk memiliki kekuatan spiritual keagamaan, pengendalian diri, keperibadian, kecerdasan, ahlak mulia, serta keterampilan yang diperlukan dirinya, masyarakat bangsa dan negara.Dewi (2014) berpendapat bahwa pendidikan di Indonesia masih berkutat pada permasalahan kualitas atau mutu pendidikan. Berbagai upaya telah dilakukan pemerintah untuk meningkatkan mutu pendidikan di Indonesia. Salah satu upaya yang dilakukan adalah dengan menyempurnakan kurikulum.

Menurut Ruhimat, dkk (2011) kurikulum adalah sejumlah rencana isi yang merupakan sejumlah tahapan belajar yang didesain untuk siswa dengan petunjuk institusi pendidikan yang isinya berupa proses yang statis ataupun dinamis dan kompetensi yang harus dimiliki. Tahapan belajar anak SD di Indonesia berumur 7 sampai 12 tahun berada pada tahapan operasi konkret, pada tahapan ini anak sudah mulai berfikir logis sebagai akibat adanya kegiatan memanipulasi benda-benda konkret. Menurut Susanto (2013) pendidikan SD tidak semata-mata membekalianak didik berupa kemampuan membaca, menulis, dan berhitung semata tetapi harus mengembangkan potensi mental, sosial dan spiritual. SD memiliki visi mengembangkan manusia yang beriman dan bertakwa kepada Tuhan Yang Maha Esa, berahlak mulia, sehat, beriman, cakap, kreatif, mandiri, dan menjadi warga negara yang demokratis dan bertanggung jawab. Salah satu mata pelajaran yang mencangkup kemampuan membaca, menulis, dan berhitung yang ada di SD yaitu mata pelajaran Matematika. Tujuan pembelajaran matematika di SD, yaitu: (1) memahami konsep matematika, (2) mampu memecahkan masalah yang berkaitan dengan matematika dan, (3) memiliki sikap menghargai penggunaan matematika dalam kehidupan sehari-hari, untuk mencapai tujuan pembelajaran matematika tersebut, seorang guru hendaknya dapat menciptakan kondisi, dan situasi pembelajaran yang memungkinkan siswa aktif membentuk, menemukan, dan mengembangkan pengetahuannya. Kemudian siswa dapat membentuk makna dari bahan-bahan pelajaran melalui suatu proses belajar dan menerapkannnya dalam kehidupan sehari-hari.

Proses pembelajaran matematika perlu mendapat perhatian dan penanganan yang serius. Hal ini penting sebab dari hasil observasi yang telah dilakukan pada hari rabu, 29 November 2017 bahwa proses pembelajaran matematika di Gugus III Kecamatan Banjar, Kabupaten Buleleng belum menunjukkan hasil yang memuaskan. Hal ini dapat dilihat dari hasil rata-rata nilai UAS matematika, siswa kelas III Semester I di Gugus III Kecamatan Banjar, Kabupaten Buleleng tahun pelajaran 2017/2018 yang belum memenuhi KKM. Jumlah siswa yang mencapai KKM sebanyak 44 siswa dan yang belum mencapai KKM sebanyak 86 siswa dari total 86 siswa. Jika dilihat dari persentase pencapaian KKM, sebanyak $62,37 \%$ yang belum mencapai KKM dan hanya 37,63\% yang mencapai KKM. Jadi dari data tersebut dapat disimpulkan bahwa hasil belajar siswa khususnya pada mata pelajaran Matematika masih rendah.

Hasil wawancara dengan kepala sekolah dan wali kelas di masing-masing sekolah di Gugus III Kecamatan Banjar, Kabupaten Buleleng bahwa rendahnya nilai UAS mata pelajaran Matematika pada semester I disebabkan oleh beberapa faktor, yaitu: (1) kurangnya pemahaman, dan penerapan materi yang diajarkan oleh guru, (2) kurangnya minat dan motivasi siswa untuk belajar, dan (3) sedikit siswa yang mau menyampaikan pendapat (pembelajaran masih pasif). Berdasarkan hasil observasi dan wawancara yang sudah dilakukan, hasil belajar matematika kelas III SD di Gugus III semester I Kecamatan Banjar, Kabupaten Buleleng masih rendah, maka inovasi pembelajaran perlu dilakukan untuk meningkatkan hasil belajar matematika.

Tahap pemahaman siswa kelas III SD masih termasuk dalam tahap operasional konkret. Pemahaman sesuatu yang abstrak sebaiknya dihubungkan dengan benda konkret, sehingga diharapkan dengan meningkatnya pemahaman siswa, dapat meningkatkan hasil belajar siswa. Mengacu pada permasalahan-permasalahan yang ditemui di lapangan, guru hendaknya mengetahui, memilih, dan mampu mengembangkan model pembelajaran yang sesuai dengan kondisi dan karakteristik siswa SD serta sesuai dengan pembelajaran matematika yang akan diajarkan.

Solusi yang dapat ditawarkan dalam meningkatkan hasil belajar matematika siswa adalah dengan menerapkanmodel pembelajaran CTL. Menurut Trianto (2009) model pembelajaran CTL adalah model yang membantu guru mengaitkan antara materi yang diajarkan dengan situasi dunia nyata siswa, dan mendorong siswa membuat hubungan antara pengetahuan yang dimilikinya, dengan penerapannya dalam kehidupan mereka seharihari. Kurangnya minat, dan motivasi siswa untuk belajar, dan sedikit siswa yang mau menyampaikan pendapat akan mempengaruhi hasil belajar siswa, oleh karena itu selain menerapkan model pembelajaran CTL, peneliti juga akan menerapkan Tri Kaya Parisudha dalam proses pembelajaran matematika.

Menurut Mardana, dkk (2005) Tri Kaya Parisudha artinya tiga perilaku/perbuatan yang harus disucikan. Pikiran, perkataan, dan perbuatan yang baik dan benar sangat dianjurkan dalam ajaran agama. Pikiran yang kotor 
perlu dikendalikan agar dapat berpikir yang baik dan benar, ucapan yang kotor perlu dikendalikan agar dapat berkata yang baik dan benar, dan perbuatan yang kotor juga harus dikendalikan agar menimbulkan perbuatan yang baik dan benar. Tri Kaya Parisudha harus dilaksanakan dalam kehidupan sehari-hari seperti dalam kegiatan pendidikan, yang akan menghasilkan individu-individu yang berkarakter. Pernyataan ini sejalan dengan Peraturan Presiden Nomor 87 Tahun 2017 Pasal 1 Ayat 1 Tentang Penguatan Pendidikan Karakter.

Penanaman pendidikan karakter dalam Tri Kaya Parisudha tidak hanya sebatas pengarahan dari guru kepada siswa, namun seorang guru harus menjadi tauladan dalam mengimplikasikan nilai-nilai Tri Kaya Parisudha. Saat pelaksanaan pembelajaran seorang guru harus dapat mengendalikan pikiran dengan cara memandang sesuatu secara positif, berpikir sesuatu yang bermanfaat, dan tidak mudah marah. Mengendalikan perkataan, misalnya dengan cara tidak berkata kasar di hadapan siswa, mengantarkan materi pelajaran dengan tutur kata yang santun, dengan suara yang enak didengar dan jelas sehingga tidak menimbulkan kesalah pahaman. Terakhir guru perilaku yang baik, misalnya membimbing siswa dengan sabar dalam proses pembelajaran. Melalui hal tersebut siswa akan terbiasa mendengar dan melihat langkah konkrit dari pelaksanaan nilai-nilai yang terkandung dalam Tri Kaya Parisudha. Tauladan para guru juga dapat mempengaruhi perilaku-perilaku siswa.

Penerapan model pembelajaran CTL berorientasi Tri Kaya Parisudha terpadu dalam langkah-langkah penerapan CTL dalam kelas sebagai berikut: (1) kembangkan pemikiran bahwa anak akan belajar lebih bermakna dengan cara bekerja sendiri, menemukan sendiri, dan mengonstruksi sendiri pengetahuan dan keterampilan barunya, (2) laksanakan sejauh mungkin kegiatan inkuiri untuk semua topik, (3) kembangkan sifat ingin tahu siswa dengan bertanya, (4) ciptakan masyarakat belajar (belajar dalam kelompok-kelompok), (5) hadirkan model sebagai contoh pembelajaran, (6) lakukan refleksi di akhir pertemuan, dan (7) lakukan penilaian yang sebenarnya dengan berbagai cara. Penerapan model CTL juga akan meninjau tiga perilaku manusia yang baik yaitu Tri Kaya Parisudha.

Tujuan penelitian ini adalah untuk mengetahui perbedaan hasil belajar matematika antara siswa yang dibelajarkan menggunakan model pembelajaran CTLberorientasi Tri Kaya Parisudha, dengan siswa yang tidak dibelajarkan menggunakan model pembelajaran CTLberorientasi Tri Kaya Parisudha, terhadap mata pelajaran Matematika siswa kelas III SD di Gugus III semester II Kecamatan Banjar, Kabupaten Buleleng tahun pelajaran 2017/2018.

Berdasarkan uraian tersebut, dipandang perlu dilakukan penelitian eksperimen dengan judul"Pengaruh Model Pembelajaran CTLBerorientasi Tri Kaya Parisudha Terhadap Hasil Belajar Matematika Pada Siswa Kelas III SD Di Gugus III Semester II Kecamatan Banjar, Kabupaten Buleleng Tahun Pelajaran 2017/2018”.

\section{Metode Penelitian}

Penelitian ini merupakan penelitian eksperimen, karena mengungkapkan hubungan sebab dan akibat dengan cara melibatkan kelompok kontrol, dan kelompok eksperimen. Pada penelitian yang akan dilakukan, tidak memungkinkan untuk mengadakan kontrol/manipulasi terhadap semua variabel yang relevan. Oleh karena itu, penelitian ini termasuk penelitian eksperimen semu (quasi experiment). Disebut demikian karena penentuan subjek penelitian tidak dirandom secara individu, melainkan melalui proses randomisasi pada kelas-kelas yang utuh atau random sampling.

Populasi dalam penelitian adalah seluruh kelompok siswa kelas III SD di Gugus III Kecamatan Banjar, Kabupaten Buleleng yang berjumlah tujuh kelas yang terdiri dari 130 siswa dan terbagi dalam tujuh SD yaitu SD Negeri 1 Dencarik dengan jumlah 25 siswa, SD Negeri 2 Dencarik dengan jumlah 25 siswa, SD Negeri 3 Dencarik dengan jumlah 20 siswa, SD Negeri 1 Tampekan dengan jumlah 15 siswa, SD Negeri 1 Banjar Tegeha dengan jumlah 18 siswa, SD Negeri 3 Banjar Tegeha dengan jumlah 10 siswa dan SD Negeri 4 Banjar dengan jumlah 17 siswa. Keseluruhan populasi adalah 130 siswa.

Sampel ditentukan dengan teknik random sampling yaitu pemilihan sampel secara acak atau random. Teknik ini digunakan sebagai teknik pengambilan sampel karena individu-individu pada populasi telah terdistribusi ke dalam kelas-kelas sehingga tidak memungkinkan untuk melakukan pengacakkan terhadap individu-individu dalam populasi.Tahap pertama dari tujuh sekolah yang ada di Gugus III Kecamatan Banjar, Kabupaten Buleleng dilakukan pengundian untuk diambil dua kelompok yang dijadikan sampel penelitian. Kedua kelompok tersebut diundi lagi untuk menentukan kelompok eksperimen yang mendapat perlakuan model pembelajaran CTL berbasis Tri Kaya Parisudha, dan satu kelompok sebagai kelompok kontrol yang tidak mendapat perlakuan model pembelajaran CTL berbasis Tri Kaya Parisudha atau pembelajaran berlangsung seperti biasanya yang dilakukan oleh guru. Berdasakan hasil pengundian untuk menentukan kelompok eksperimen dan kontrol, diperoleh kelas III SD Negeri 3 Dencarik sebagai kelompok eksperimen dengan perlakuan model pembelajaran CTL berorientasi Tri Kaya Parisudha, sedangkan kelompok kontrol diperoleh kelas III SD Negeri 2 Dencarik tanpa perlakuan model pembelajaran CTL berorientasi Tri Kaya Parisudha.

Penelitian ini melibatkan dua variabel, yaitu model pembelajaran CTL berorientasi Tri Kaya Parisudha sebagai variabel bebas dan hasil belajar matematika sebagai variabel terikat. Pada kelas eksperimen dibelajarkan menggunakan model pembelajaran CTL berorientasi Tri Kaya Parisudha, sedangkan pada kelas kontrol tidak tidak 
dibelajarkan menggunakan model pembelajaran CTL berorientasi Tri Kaya Parisudha. Pembelajaran dilakukan sebanyak 7 kali pertemuan dan satu kali post test. Hasil belajar matematika diukur melalui post test.

Data yang diperlukan dalam penelitian, yaitu data hasil belajarmatematika. Bentuk tes hasil belajar yang digunakan berupa soal objektif (pilihan ganda). Pengumpulan data dalam penelitian ini mengunakan metode tes.Metode tes yang digunakan dalam penelitian ini adalah prosedur yang menggunakan sejumlah tes hasil belajar dalam bentuk objektif. Instrumen yang digunakan untuk memperoleh data tentang hasil belajar matematika terdiri dari 25 soal. Setiap jawaban diberikan skor 1 jika menjawab benar dengan alasan yang tepatdan skor 0 jika tidak menjawab sama sekali. Skor setiap jawaban kemudian dijumlahkan dan jumlah tersebut merupakan skor hasil belajar siswa.

Metode analisis data yang digunakan dalam penelitian ini adalah metode analisis statistik deskriptif dan statistik inferensial (uji-t). Analisis deskriptif digunakan untuk mengetahui deskripsi hasil belajar matematika dengan mencari nilai mean, median, modus, standar deviasi, rentangan, dan varian. Selanjutnya, statistik inferensial digunakan untuk melakukan uji hipotesis. Sebelum uji hipotesis, dilakukan beberapa uji prasyarat berupa uji normalitas dan uji homogenitas, sedangkan metode analisis data yang digunakan untuk menguji hipotesis adalah analisis uji-t.

\section{Hasil Penelitian Dan Pembahasan}

Hasil analisis deskriptif data hasil belajar matematika pada kelompok eksperimen menunjukkan bahwa skor rata-rata adalah 17,95 dengan kategori tinggi dan pengukuran hasil belajar matematika pada kelompok kontrol menunjukkan bahwa skor rata-rata adalah 14,6 dengan kategori sedang. Rangkuman hasil deskripsi data hasil belajar matematika pada penelitian ini dapat dilihat pada Tabel 1 .

Tabel 1.

Rangkuman Deskrispsi Data Hasil Belajar Matematika

\begin{tabular}{ccc}
\hline \multirow{2}{*}{ Statistik Deskriptif } & \multicolumn{2}{c}{ Hasil Belajar Matematika } \\
\cline { 2 - 3 } & Kelompok Eksperimen & Kelompok Kontrol \\
\hline Mean & 17,95 & 14,6 \\
Median & 18,21 & 14,55 \\
Modus & 18,9 & 14,16 \\
Varians & 12,58 & 16,42 \\
Standar Deviasi & 3,55 & 4,05 \\
Skor Maksimum & 24 & 24 \\
Skor Minimum & 8 & 8 \\
Rentangan & 16 & 16 \\
\hline
\end{tabular}

Hasil analisis despriptif pada Tabel 1. skor rata-rata hasil belajar matematika kelompok eksperimen lebih besar dibandingkan skor rata-rata hasil belajar matematika kelompok kontrol. Tinjauan ini didasarkan pada rata-rata skor dan kecenderungan skor hasil belajar matematika yang diperoleh kedua kelompok.

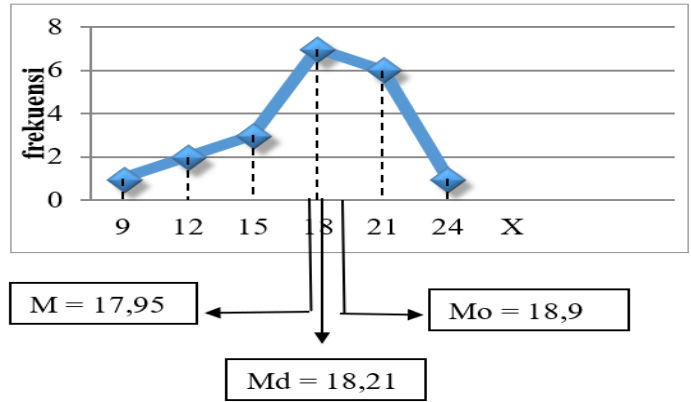

Gambar 1.

Kurva Poligon Data Hasil Belajar matematika Kelompok Eksperimen

Pada Gambar1. dapat diketahui bahwa modus lebih besar dari median dan median lebih besar dari mean $(\mathrm{Mo}>\mathrm{Md}>\mathrm{M})$. Dengan kata lain, grafik di atas adalah grafik juling negatif.Artinya, sebagian besar skor cenderung tinggi. Kecenderungan skor ini dapat dibuktikan dengan melihat frekuensi relatif pada tabel distribusi frekuensi. 
Frekuensi relatif skor yang berada di atas rata-rata lebih besar dibandingkan frekuensi relatif skor yang berada di bawah rata-rata. Rata-rata skor hasil belajar matematika pada kelompok eksperimen adalah 17,95 tergolong kriteria "Tinggi" dan sebagain besar skor siswa cenderung tinggi.

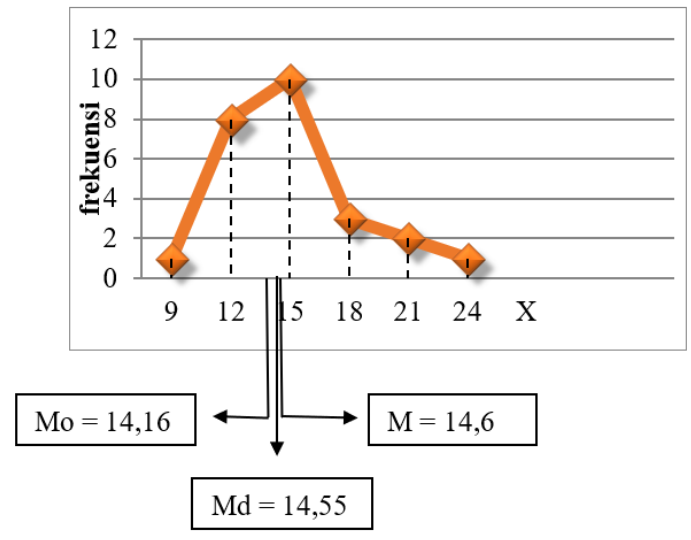

Gambar 2 .

Kurva Poligon Data Hasil Belajar matematika Kelompok Kontrol

Pada Gambar 2. dapat diketahui bahwa modus lebih kecil dari median dan median lebih kecildari mean $(\mathrm{Mo}<\mathrm{Md}<\mathrm{M})$. Dengan kata lain, grafik di atas adalah grafik juling positif.Artinya, sebagian besar skor cenderung rendah. Kecenderungan skor ini dapat dibuktikan dengan melihat frekuensi relatif pada tabel distribusi frekuensi. Frekuensi relatif skor yang berada di atas rata-rata lebih kecil dibandingkan frekuensi relatif skor yang berada di bawah rata-rata.Rata-rata skor hasil belajar matematika pada kelompok kontrol adalah 14,16 tergolong kriteria "Sedang". dan sebagain besar skor siswa cenderung rendah.

Berdasarkan paparan tersebut, hasil belajar matematika pada kelompok eksperimen lebih baik daripada hasil belajar matematika pada kelompok kontrol. Hasil uji prasayat analisis menunjukkan data berdistribusi normal dan memiliki varians yang homogen. Berdasarkan hasil ujihipotesis yang telah dilakukan, menunjukkan bahwa nilai $\mathrm{t}_{\text {hitung }}=3,22$ sedangkan $\mathrm{t}_{\text {tab }}$ dengan $\mathrm{dk}=20+25-2=43$ dantaraf signifikansi $5 \%$ adalah 1,68 . Hal ini berarti, $\mathrm{t}_{\text {hit }}$ lebih besar dari $t_{\text {tab }}\left(t_{\text {hit }}>t_{t a b}\right)$, sehingga hasilnya signifikan.Dengan demikian $\mathrm{H}_{1}$ diterima dan $\mathrm{H}_{0}$ ditolak, yang berarti terdapat perbedaan yang signifikan hasil belajar matematika antara siswa yang dibelajarkan menggunakan model pembelajaran CTL berorientasi Tri Kaya Parisudha dan siswa yang tidak dibelajarkan menggunakan model pembelajaran CTL berorientasi Tri Kaya Parisudha pada siswa kelas III SD di Gugus III Semester II Kecamatan Banjar, Kabupaten Buleleng tahun pelajaran 2017/2018.

\section{Pembahasan}

Hasil penelitian menunjukkan bahwa, terdapat perbedaan hasil belajar matematika antara kelompok siswa yang dibelajarkan menggunakan model pembelajaran CTL berorientasi Tri Kaya Parisudha, dengan kelompok siswa yang tidak dibelajarkan menggunakanmodel pembelajaran CTL berorientasi Tri Kaya Parisudha. Secara deskriptif, hasil belajar matematika siswa kelompok eksperimen lebih tinggi dibandingkan dengan siswa kelompok kontrol. Tinjauan ini didasarkan pada rata-rata skor hasil belajar matematika dan kecenderungan skor hasil belajar matematika, serta pada uji prasyarat analisis data, diperoleh data hasil penguasaan dimensi proses kognitif siswa kelompok eksperimen dan kontrol adalah normal dan homogen. Setelah diperoleh hasil uji prasyarat analisis data, analisis dilanjutkan dengan pengujian hipotesis, pada taraf signifikan 5\%diperoleh $\mathrm{H}_{0}$ ditolak dan $\mathrm{H}_{1}$ diterima,dengan demikian dapat diinterpretasikan bahwa terdapat perbedaan yang singnifikan hasil belajar matematika antara kelompok siswa yang dibelajarkan menggunakan model pembelajaran CTL berorientasi Tri kaya Parisudha dan kelompok siswa yang tidak dibelajarkan menggunakan model pembelajaran CTL berorientasi Tri kaya Parisudha pada siswa kelas III SD di Gugus III semester II Kecamatan Banjar Kabupaten Buleleng tahun pembelajaran 2017/2018.

Perbedaan hasil belajar antara kelompok siswa yang dibelajarkan menggunakan model pembelajaran CTL berorientasi Tri kaya Parisudhadengan kelompok siswa yang tidak dibelajarkan menggunakan model pembelajaran CTL berorientasi Tri kaya Parisudha disebabkan adanya perbedaan perlakuan pada proses pembelajaran. Hal itu dikarenakan pada model pembelajaran CTL berorientasi Tri kaya Parisudha siswa dilibatkan secara penuh dalam pembelajaran dan melatih sikap kesiapan siswa, meningkatkan keaktifan siswa mengikuti pembelajaran dan meningkatkan pemahaman materi yang diajarkan, karena dalam pembelajaran guru mengaitkan materi dengan 
benda nyata, serta meninjau kembali Tri kaya Parisudha dalam pembelajaran yaitu manacika, wacika dan kayika. Penerapan manacika dalam diskusi siswa mampu berpikir yang baik dengan kelompoknya, wacika siswa mampu berkata atau berkomunikasi yang baik terhadap kelompoknya, serta kayika siswa mampu mengerjakan tugas yang diberikan oleh guru dengan baik.

Peningkatan dapat terjadi karena beberapa hal. Pertama, pembelajaran yang menerapkan model pembelajaran CTL berorientasi Tri kaya Parisudhadapat mengubah pembelajaran yang awalnya berpusat pada guru menjadi pembelajaran yang berpusat pada siswa. Siswa menjadi lebih termotivasi dan aktif dalam mengikuti pembelajaran. Dalam penerapan model pembelajaran CTL berorientasi Tri kaya Parisudha, siswa mampu mengaitkan materi dengan benda nyata serta siswa mampu menerapkan bagian-bagian Tri Kaya Parisudha dengan baik, sehingga hasil belajar matematika siswa meningkat.

Menurut Riastini (2016) hasil belajar merupakan hasil yang diperoleh setelah siswa melakukan kegiatan belajar. Siswa yang belajar berarti menggunakan kemampuan kognitif (kemampuan intlektual), afektif (sikap) dan psikomotor (keterampilan) terhadap lingkungan. Kegiatan belajar akan membuahkan hasil belajar pada ketiga kemampuan tersebut. Model pembelajaran yang digunakan dalam penelitian ini adalah model pembelajaran CTL berorientasi Tri Kaya Parisudha. Menurut Trianto (2009:107) "model pembelajaran CTL adalah model yang membantu guru mengaitkan antara materi yang diajarkan dengan situasi dunia nyata siswa, dan mendorong siswa membuat hubungan antara pengetahuan yang dimilikinya, dengan penerapannya dalam kehidupan mereka seharihari”. Menurut Shoimin (2014) model pembelajaran CTL merupakan merupakan suatu model pembelajaran yang holistic, dan bertujuan memotivasi siswa untuk memahami makna materi pelajaran yang dipelajarinya dengan mengaitkan materi tersebut dengan konteks kehidupan sehari-hari (konteks pribadi, sosial, dan kultural) sehingga siswa memiliki pengetahuan atau keterampilan yang secara fleksibel dapat diterapkan dari satu permasalahan ke permasalahan lainnya. Kelebihan dari model pembelajaran CTL, yaitu: (a) model pembelajaran CTL dapat menekankan aktivitas berpikir siswa secara penuh, baik fisik maupun mental, (b) model pembelajaran CTL dapat menjadikan siswa belajar bukan dengan menghafal, melainkan proses berpengalaman dalam kehidupan nyata, (c) kelas dalam penerapan model pembelajaran CTL bukan sebagai tempat untuk memproleh informasi, melainkan sebagai tempat untuk menguji data hasil temuan mereka di lapangan, dan (d) materi pelajaran ditemukan oleh siswa sendiri, bukan hasil pemberian dari orang lain.

Menurut Arsani (2012) Tri Kaya Parisudhadigunakan karena dalam kehidupan masyarakat Bali dijadikan pedoman untuk berpikir, berbicara dan berperilaku yang sesuai dengan nilai-nilai kehidupan. Jadi, Tri Kaya Parisudha akan membantu proses menanamkan nilai-nilai moral dan norma pada siswa. Menurut Danu (2014) Tri Kaya Parisudha menjelaskan tentang tiga perilaku yang harus disucikan. Timbulnya bermacam-macam penderitaan dalam hidup ini, sesungguhnya bersumber dari tiga hal yaitu: perbuatan, perkataan, dan pikiran. Sedangkan pikiran adalah kendali utama dalam mengendalikan indria-indria, seperti pada sloka 6.6 dalam kitab suci Bhagavad Gita, yaitu

\section{Bandhur atmatmanas tasya yenatmaivatmana jitah}

Anatmanas tu satrutve vartetatmaiva satru-vat

Artinya:

Pikiran adalah kawan yang paling baik bagi orang yang sudah menaklukkan pikiran, tetapi bagi orang yang gagal mengendalikan pikiran, maka pikirannya akan tetap sebagai musuh yang paling besar.

Menurut Singer (2013) pengendalian diri seperti di atas semua bertujuan untuk mencapai keharmonisan dalam kehidupan sehari-hari. Melalui tiga unsur tersebut yaitu pikiran, perkataan dan perbuatan yang seharusnya dilakukan setiap saat dan terus menerus, berdisiplin, sehingga akhirnya menjadi kebiasaan. Pikiranlah yang seharusnya paling dulu dikendalikan, yang akan diikuti oleh unsur-unsur lainnya.

Menurut Atmaja, dkk (2010) bagian-bagian Tri Kaya Parisudha, yaitu: (a) manacika yaitu berpikir yang baik, secara umum seseorang dapat dikatakan berpikir yang baik apabila ia tidak menginginkan sesuatu yang tidak halal, tidak berpikir buruk terhadap sesama manusia atau makhluk lainnya, yakin dan percaya terhadap hukum karmapala, dan secara khusus dalam proses pembelajaran matematika, yaitu berpikir bahwa mata pelajaran Matematika menyenangkan, berpikir yang baik dalam menerima pengetahuan dari guru dan teman, dan berpikir yang baik sesam teman, guru dan lingkungan, (b) wacika yaitu berkata yang baik, secara umum seseorang dapat dikatakan berkata yang baik, apabila ia tidak mencaci maki orang lain, tdak berkata-kata yang kasar kepada orang lain, tidak memfitnah atau mengadu domba, dan tidak ingkar janji,dan secara khusus dalam proses pembelajaran matematika, yaitu bertanya dan menjawab pertanyaan dengan baik, menyampaikan hasil diskusi dengan baik, dan berkomunikasi dengan baik, dan (c) kayika yaitu berbuat yang baik, secara umum seseorang dapat dikatakan berbuat yang baik, apabila ia tidak menyiksa, menyakiti atau membunuh, tidak berbuat curang, mencuri atau merampok, dan tidak berzina,dan secara khusus dalam proses pembelajaran matematika, yaitu tidak mencontek, tidak bermain-main saat guru menjelaskan di depan kelas, menghargai pendapat teman, dan tidak membuat PR di sekolah. 
Pada kelompok kontrol siswa tidak dibelajarkan menggunakan model pembelajaran CTL berorientasi Tri Kaya Parisudha melainkan pembelajaran berlangsung seperti biasa menggunakan RPP yang dibuat disekolah. Dampaknya siswa mampu mengikuti pembelajaran dengan baik, namun siswa belum mampu memahami materi pembelajaran dengan baik, serta siswa kurang aktif mengikuti pembelajaran.

Perbedaan tersebut dapat memberikan dampak yang berbeda pula terhadap hasil belajar matematika antara pembelajaran yang menggunakan model pembelajaran CTL berorientasi Tri Kaya Parisudha dengan pembelajaran yang tidak menggunakan model pembelajaran CTL berorientasi Tri Kaya Parisudha. Dengan demikian, dapat disimpulkan bahwa model pembelajaran CTL berorientasi Tri Kaya Parisudha berpengaruh positif terhadap hasil belajar matematika siswa kelas III SD Negeri 3 Dencarik, Kecamatan Banjar Kabupaten Buleleng tahun pelajaran 2017/2018.

Temuan hasil penelitian di atas sesuai dengan temuan sebelumnya. Temuan penelitian tersebut antara lain sebagai berikut. Aryani (2013) menyatakan model pembelajaran CTL dapat meningkatkan aktivitas dan hasil belajar IPA, dampaknya siswa yang awalnya kurang aktif menjadi aktif dalam mengikuti pembelajaran. Dewi (2014) menyatakan model pembelajaran numbered head together berlandaskan Tri kaya Parisudha dapat meningkatkan hasil belajar IPA, dampaknya meningkatnya motivasi, interaksi dan tanggung jawab siswa serta hasil belajar siswa. Ratih (2014) menyatakan pendekatan CTL melalui permodelan media sederhana berpengaruh terhadap hasil belajar matematika bisa membuat siswa lebih aktif dalam proses pembelajaran, siswa lebih berani mengungkapkan pendapatnya sendiri dan siswa mendapatkan ide-ide yang baru.

Hasil penelitian menunjukan bahwa terdapat perbedaan yang signifikan hasil belajar matematika antara siswa yang dibelajarakan dengan menggunakan model pembelajaran CTL berorientasi Tri Kaya Parisudhadan siswa yang tidak dibelajarkan menggunakan model pembelajaran CTL berorientasi Tri Kaya Parisudha pada siswa kelas III semester III di SD Gugus III Kecamatan Banjar Kabupaten Buleleng.

\section{Simpulan dan Saran}

Berdasarkan rumusan masalah dan hasil penelitian, maka simpulan dalam penelitian ini adalah terdapat perbedaan hasil belajar matematika antara siswa yang dibelajarkan menggunakan model pembelajaran CTL berorientasi Tri kaya Parisudhadengan kelompok siswa yang tidak dibelajarkan menggunakan model pembelajaran CTL berorientasi Tri kaya Parisudha pada siswa kelas III di Gugus III semester II Kecamatan Banjar Kabupaten Buleleng tahun pelajaran 2017/2018. Hal ini ditunjukkan pada hasil hipotesis uji-t yang diketahui bahwa $t_{\text {hitung }}=$ $1,79>t_{\text {tabel }}=1$,68berarti $\mathrm{H}_{0}$ ditolak dan $\mathrm{H}_{1}$ diterima. Hal ini berarti terdapat perbedaan hasil belajar antara siswa yang dibelajarkan menggunakan model pembelajaran CTL berorientasi Tri kaya Parisudha dengan kelompok siswa yang tidak dibelajarkan menggunakan model pembelajaran CTL berorientasi Tri kaya Parisudha pada siswa kelas III di Gugus III semester II Kecamatan Banjar Kabupaten Buleleng tahun pelajaran 2017/2018.

\section{Saran}

Saran yang dapat disampaikan berdasarkan penelitian yang telah dilakukan adalah sebagai berikut. (1) Saran yang dapat diberikan kepada siswa SD yaitu agar lebih fokus dan aktif dalam proses pembelajaran untuk dapat meningkatkan karakter siswa, serta melalui penerapan model pembelajaran ini siswa bisa meningkatkan hasil belajar matematika. (2) Guru SD Hendaknya lebih mengkreasikan pembelajaran dengan cara menerapkan modelmodel pembelajaran yang inovatif,salah satunya adalah model pembelajaran CTL berorientasi Tri Kaya Parisudha yang dapat meningkatkan hasil belajar siswa khususnya pada mata pelajaran Matematika, sebab telah terbukti pada penelitian ini bahwa terdapat perbedaan hasil belajar siswa yang signifikan antara siswa yang dibelajarkan menggunakan model pembelajaran CTL berorientasi Tri Kaya Parisudha dan siswa yang tidak dibelajarkan menggunakan CTL berorientasi Tri Kaya Parisudha. (3) Kepala sekolah hendaknya mampu mengambil tindakan dalam upaya meningkatkan kualitas pembelajaran melalui pengarahan kepada guru-guru sebagai alternatif pilihan menggunakan model pembelajaran inovatif, salah satunya CTL berorientasi Tri Kaya Parisudha. (4) Peneliti yang berminat untuk mengadakan penelitian lebih lanjut tentang model pembelajaran CTL berorientasi Tri Kaya Parisudha dalam bidang matematika maupun bidang ilmu lainnya yang sesuai agar memperhatikan kendala-kendala yang di alami dalam penelitian ini sebagai bahan pertimbangan untuk perbaikan dan penyempurnaan penelitian yang akan dilaksanakan.

\section{Daftar Pustaka}

Agung, A. A. G. 2014. Buku AjarMetodologi Penelitian Pendidikan. Yogyakarta: Aditya Media Publishing 
Arsani. S. 2012. Pengaruh Metode Pembelajaran Bermain Peran Berorientasi Kearifan Lokal Tri Kaya Parisudha Terhadap Hasil Belajar Pendidikan Kewarganegaraan Siswa Kelas V SD.E-Journal Mimbar PGSD Universitas Pendidikan Ganesha, Volume 1.

Aryani. 2013. "Penerapan Model Pembelajaran CTL (Contectual Teaching Learning) Berbantuan Media Gambar untuk Meningkatkan Aktivitas dan Hasil Belajar IPA Siswa Kelas V”. E-Journal Mimbar PGSD Universitas Pendidikan Ganesha, Volume 1.

Atmaja, I. M. N, Arniati, I.A.K. 2010. Etika Hindu. Surabaya: Paramita

Danu, I. M. 2014. Ajaran Weda dalam Filosofi Hindu. Surabaya: Paramita.

Dewi. Candra. 2014. "Pengaruh Model Pembelajaran Numbered Head Together Berlandaskan Tri Kaya Parisudha Terhadap Hasil Belajar IPA Siswa Kelas V”. E-Journal Mimbar PGSD Universitas Pendidikan Ganesha, Volume 2, Nomor 1.

Mardana. I. N, Sumartawan. I. K., dkk. 2005. Semara Ratih Pendidikan Agama Hindu. Denpasar: Perpustakaan Nasional.

Peraturan Presiden Nomor 87 Tahun 2017 Tentang Penguatan Pendidikan Karakter. 2017. Departemen Pendidikan Nasional.

Ratih. 2014. "Pengaruh Pendekatan Contextual Teaching And Learning (CTL) Melalui Pemodelan Media Sederhana Terhadap hasil Belajar Matematika Siswa Kelas V SD Gugus III Kecamatan Gianyar”. E-Journal Mimbar PGSD Universitas Pendidikan Ganesha, Volume 2, No 1.

Riastini, P. N. 2016. Pembelajaran IPA SD. Singaraja. Undiksha Singaraja.

Ruhimat, T., Ibrahim, R. 2011. Kurikulum dan Pembelajaran. Jakarta: PT RajaGrafindo Persada.

Shoimin, A. 2014. 68 Model Pembelajaran Inovatif dalam Kurikulum 2013. Yogyakarta: Ar-Ruzz Media.

Singer, I. W. 2013. Tata Susila Hindu. Surabaya: Paramita

Susanto, A. 2013. Teori Belajar dan Pembelajaran di Sekolah Dasar. Jakarta: Kencana Prenada Media Group.

Trianto. 2009. Mendesain Model Pembelajaran Inovatif-Progresif Konsep, Landasan, dan Implementasinya pada Kurikulum Tingkat Satuan Pendidikan (KTSP). Jakarta: Kencana Prenada Media Group.

Undang-Undang No. 20 Tahun 2003 tentang Sistem Pendidikan Nasional. 2003. Departemen Pendidikan Nasional. 